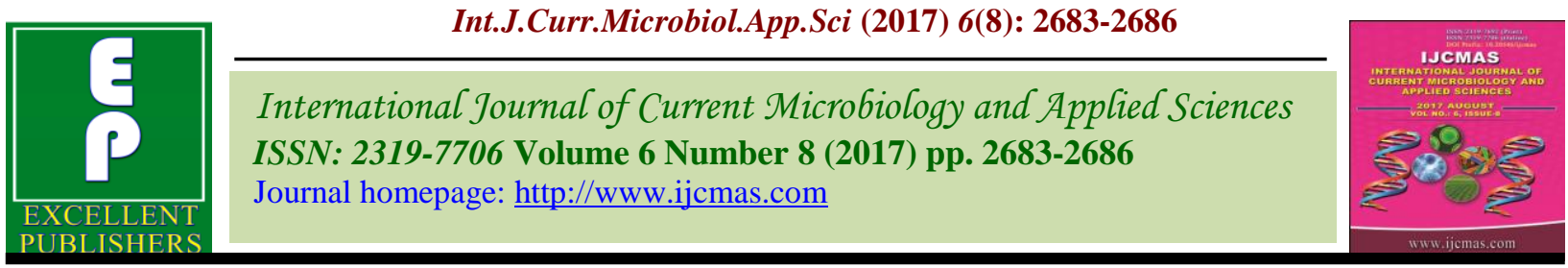

Original Research Article

https://doi.org/10.20546/ijcmas.2017.608.320

\title{
Genetic Divergence Analysis of Agronomic Traits in Bread Wheat (Triticum aestivum L.) Genotypes
}

\author{
Ajeet Kumar*, S.S. Gaurav, Amit Kumar and Vikas Rathi \\ Department Genetics and Plant Breeding, C.C.S. University Meerut-250001, UP, India \\ *Corresponding author
}

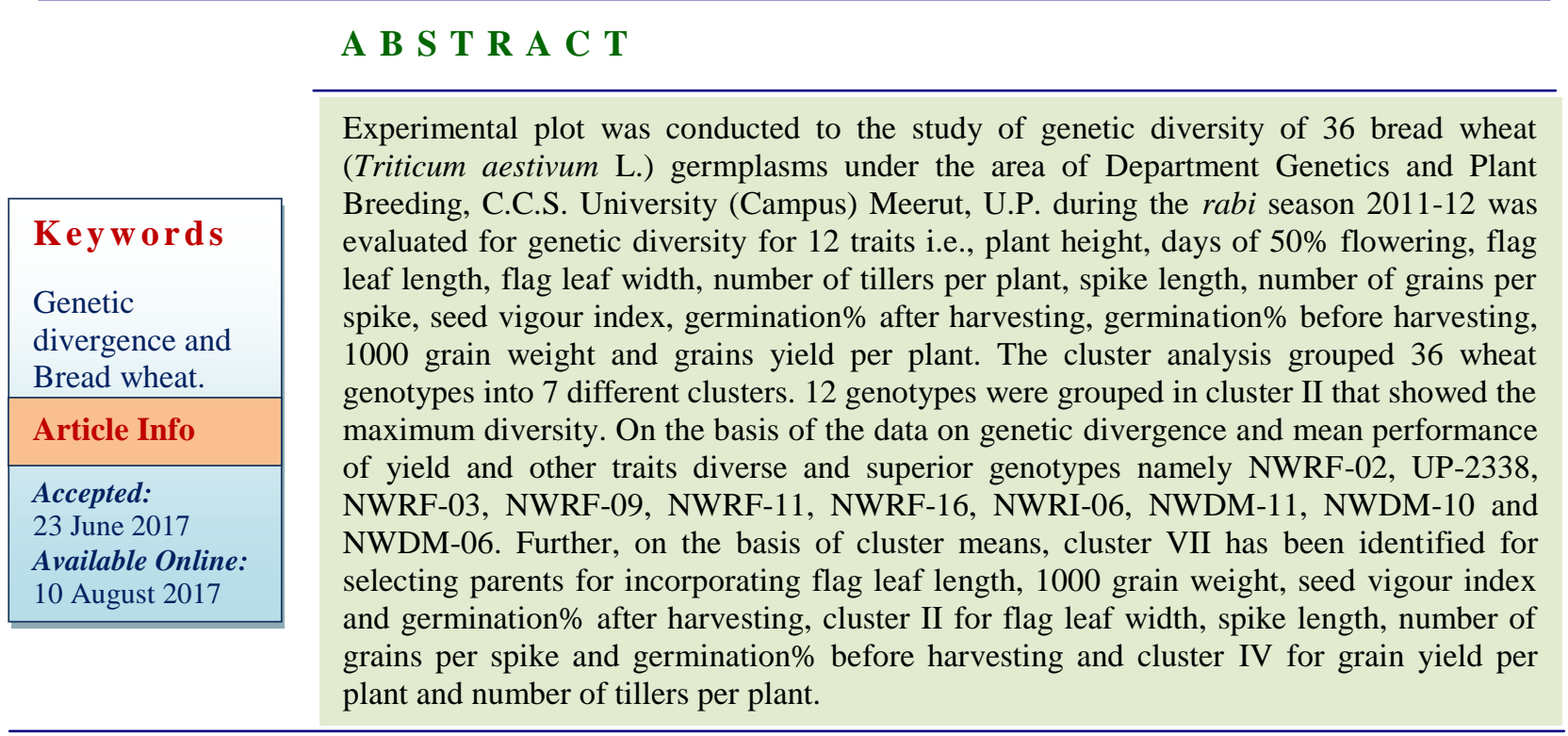

\section{Introduction}

Wheat (Triticum aestivum L.) is the most important cereal crop for the majority of world's populations. It is the most important staple food of about two billion people (36\% of the world population). Wheat belongs to family Poaceae (Gramineae) which includes major crop plants such as wheat (Triticum spp. L.), barley (Hordeum vulgare L.), oat (Avena sativa L.), rye (Secale cerealeL.), maize (Zea mays L.) and rice (Oryza sativa L.). Wheat is grown in all the states in India except Southern and North Eastern states. Uttar Pradesh, Haryana, Punjab, Rajasthan are the major wheat producing states and accounts for almost $80 \%$ of total production in India. Today, India ranks second in wheat production with a harvest of 93.9 million ton during the season 2011-12.Its cultivation area is $28 \mathrm{M} \mathrm{Ha}$. The record production of 94.88 million MT in 2011-12. The productivity of wheat which was $3140 \mathrm{~kg} / \mathrm{hectare}$ in 2011-12. The major increase in the productivity of wheat has been observed in the states of Haryana, Punjab and Uttar Pradesh.

\section{Materials and Methods}

The 36 genotypes of wheat (Triticum aestivum L.) were obtained from the Directorate of Wheat Research (DWR) Karnal, Haryana sown in the research area of Department of Genetics and Plant Breeding, 
C.C.S. University, Meerut on December 2011 with RBD field design. The experiment was laid out in R.B. Design with three replications. Each genotype in each replication was grown in a plot of 3 rows of 2 meter length each with a spacing of $10 \mathrm{~cm}$ between rows. Cluster analysis was performed by using the STATISTICA software. At maturity five guarded plants from three rows were selected at random from each plot in each replication.

\section{Results and Discussion}

\section{Genetic divergence}

On the basis of relative magnitude of $\mathrm{D}^{2}$ values, the 36 genotypes were grouped into 7 clusters having $3,12,2,4,3,3$ and 9 genotypes, respectively (Table- 1 ). The maximum number of genotypes (12) were included in cluster II followed by 9 genotypes in cluster VII and minimum number of genotype 1 in cluster III.

The cluster distance (Table 2), which reflects to some extent the genetic dissimilarity between and within groups, revealed that intra-varietal group clusters had a genetic distance that was much less ( 0.00 to 22.075 ) and then inter-varietal group clusters (21.864 to 182.092). The highest inter-cluster genetic distance was found between cluster V and VI (182.092) closely followed by II and VI (102.887), VI and VII (102.793), III and V (102.286) and III and VII (99.832). The distance was low between clusters I and IV (21.64) followed by I and II (27.139) and II and V (27.742).

For genotypes grouped into 7 clusters, mean value for 12 characters given in Table-3. The trait plant height is highest mean values (112.491) for cluster number $\mathrm{V}$ and low mean values (77.120) for cluster number VI, the trait flag leaf length is highest mean values
(23.125) for cluster number VII and low mean values (19.319) for cluster number III, the trait flag leaf width is highest mean values (1.794) for cluster number II and low mean values (1.578) for cluster number $\mathrm{V}$, the trait number of tillers per plant is highest mean values (11.000) for cluster number IV and low mean values (7.333) for cluster number VII, the trait spike length is highest mean values (12.133) for cluster number II and low mean values (7.825) for cluster number VII, the trait number of grains per spike is highest mean values (49.222) for cluster number II and low mean values (33.667) for cluster number $\mathrm{V}$, the trait 1000 -grain weight is highest mean values (45.300) for cluster number VII and low mean values (41.005) for cluster number I, the trait day of 50\% flowering is highest mean values (80.133) for cluster number VI and low mean values (63.333) for cluster number IV, the trait grain yield per plant is highest mean values (21.180) for cluster number IV and low mean values (13.087) for cluster number VI, the trait seed vigour index is highest mean values (2785.583) for cluster number VII and low mean values (2369.600) for cluster number $\mathrm{VI}$, the trait germination \% after harvesting is highest mean values (91.500) for cluster number VII and low mean values (85.833) for cluster number II, and the trait germination \% before harvesting is highest mean values (92.944) for cluster number II and low mean values (89.133) for cluster number VI. The contribution of each character to total diversity was observed and presented in table 4. Plant height (ranked first 209 times) contributed 33.17 per cent to divergence of genotypes. This was followed by day of 50\% flowering (22.70), spike length (22.06\%), flag leaf length (6.67), No of grain/spike (4.92), seed vigour index (2.86), 1000-grain weight and germination $\%$ after harvesting (2.38), flag leaf width (1.27), No of tiller/plant and germination \% before sowing (0.63) and grain yield per plant $(0.32)$. 
Table.1 Grouping of genotypes into clusters

\begin{tabular}{|c|c|l|}
\hline Clusters & No. of genotypes & Cluster Members \\
\hline I & 3 & $9,14,26$ \\
\hline II & 12 & $4,5,6,7,10,12,15,19,21,24,25,27$ \\
\hline III & 2 & 2,36 \\
\hline IV & 4 & $8,13,20,23$ \\
\hline V & 3 & $3,11,16$ \\
\hline VI & 3 & $30,31,34$ \\
\hline VII & 9 & $1,17,18,22,28,29,32,33,35$ \\
\hline
\end{tabular}

Table.2 Cluster mean among different traits in bread wheat (Triticum aestivum L)

\begin{tabular}{|c|c|c|c|c|c|c|c|c|c|c|c|c|}
\hline Character & $\begin{array}{l}\text { Day of } \\
50 \% \\
\text { flowering }\end{array}$ & $\begin{array}{l}\text { Plant } \\
\text { height } \\
(\mathrm{cm})\end{array}$ & $\begin{array}{l}\text { Flag leaf } \\
\text { length } \\
(\mathrm{cm})\end{array}$ & $\begin{array}{l}\text { Flag leaf } \\
\text { width } \\
(\mathrm{cm})\end{array}$ & $\begin{array}{l}\text { Tillers } \\
\text { / plant }\end{array}$ & $\begin{array}{l}\text { Spike } \\
\text { length } \\
\mathrm{cm}\end{array}$ & $\begin{array}{l}\text { Grains/ } \\
\text { spike }\end{array}$ & $\begin{array}{l}1000 \text { grain } \\
\text { weight in } \\
\text { (g) }\end{array}$ & $\begin{array}{l}\text { Seed } \\
\text { vigour } \\
\text { index } \\
\end{array}$ & $\begin{array}{l}\text { Germination } \\
\% \text { after } \\
\text { harvesting }\end{array}$ & $\begin{array}{l}\text { Germination } \\
\text { \% before } \\
\text { harvesting }\end{array}$ & $\begin{array}{l}\text { Grain } \\
\text { yield/ } \\
\text { plant (g) }\end{array}$ \\
\hline Cluster I & 76.292 & 85.834 & 22.058 & 1.667 & 8.583 & 11.313 & 41.375 & 41.005 & 2515.625 & 88.958 & 90.750 & 14.620 \\
\hline Cluster II & 78.278 & 93.887 & 22.756 & 1.794 & 9.000 & 12.133 & 49.222 & 41.314 & 2463.611 & 85.833 & 92.944 & 18.337 \\
\hline Cluster III & 76.111 & 91.884 & 19.319 & 1.607 & 9.704 & 10.770 & 37.296 & 41.707 & 2618.778 & 88.222 & 92.481 & 14.986 \\
\hline Cluster IV & 63.333 & 82.543 & 22.867 & 1.767 & 11.000 & 10.033 & 46.000 & 41.967 & 2400.000 & 88.333 & 91.667 & 21.180 \\
\hline Cluster V & 78.444 & 112.491 & 21.722 & 1.578 & 9.111 & 9.867 & 33.667 & 45.087 & 2675.778 & 89.556 & 92.778 & 14.054 \\
\hline Cluster VI & 80.133 & 77.120 & 19.740 & 1.660 & 7.600 & 8.473 & 38.600 & 43.693 & 2369.600 & 86.000 & 89.133 & 13.087 \\
\hline Cluster VII & 80.000 & 84.082 & 23.125 & 1.625 & 7.333 & 7.825 & 41.083 & 45.300 & 2785.583 & 91.500 & 89.250 & 14.888 \\
\hline
\end{tabular}

Table.3 Average intra (bold) and inter -cluster distance between 7 clusters for 36 genotypes of bread wheat (Triticum aestivum L.)

\begin{tabular}{|c|c|c|c|c|c|c|c|}
\hline Cluster No. & I Cluster & II Cluster & III Cluster & IV Cluster & V Cluster & VI Cluster & VII Cluster \\
\hline I Cluster & 14.412 & 27.139 & 31.068 & 21.864 & 49.128 & 68.873 & 52.515 \\
\hline II Cluster & & 10.445 & 48.101 & 45.927 & 27.742 & 102.887 & 74.586 \\
\hline III Cluster & & & 22.075 & 37.797 & 102.286 & 41.749 & 99.832 \\
\hline IV Cluster & & & & 0.000 & 74.269 & 46.143 & 35.074 \\
\hline V Cluster & & & & & 0.000 & 182.092 & 77.318 \\
\hline VI Cluster & & & & & & 0.000 & 102.793 \\
\hline VII Cluster & & & & & & & 0.000 \\
\hline
\end{tabular}

Table.4 Contribution of different traits towards diversity

\begin{tabular}{|c|c|c|c|c|c|c|c|c|c|c|c|c|}
\hline Sources & $\begin{array}{l}\text { Day of } \\
50 \% \\
\text { flowering }\end{array}$ & $\begin{array}{l}\text { Plant } \\
\text { height } \\
\text { (cm) }\end{array}$ & $\begin{array}{l}\text { Flag leaf } \\
\text { length } \\
(\mathrm{cm})\end{array}$ & $\begin{array}{l}\text { Flag leaf } \\
\text { width } \\
(\mathrm{cm})\end{array}$ & $\begin{array}{l}\text { Tillers/ } \\
\text { plant }\end{array}$ & $\begin{array}{l}\text { Spike } \\
\text { length } \\
\mathrm{cm}\end{array}$ & $\begin{array}{l}\text { Grains/ } \\
\text { spike }\end{array}$ & $\begin{array}{l}1000 \text { grain } \\
\text { weight in } \\
\text { (g) }\end{array}$ & $\begin{array}{l}\text { Seed } \\
\text { vigour } \\
\text { index }\end{array}$ & $\begin{array}{l}\text { Germination } \\
\% \text { after } \\
\text { harvesting }\end{array}$ & $\begin{array}{l}\text { Germination } \\
\text { \%before } \\
\text { harvesting }\end{array}$ & $\begin{array}{l}\text { Grain } \\
\text { yield/ } \\
\text { plant (g) }\end{array}$ \\
\hline Ranked & 143 & 209 & 42 & 8 & 4 & 139 & 31 & 15 & 18 & 15 & 4 & 2 \\
\hline Contribution \% & 22.70 & 33.17 & 6.67 & 1.27 & 0.63 & 22.06 & 4.92 & 2.38 & 2.86 & 2.38 & 0.63 & 0.32 \\
\hline
\end{tabular}


These findings are similar in agreement with earlier reported by Gupta et al., (1996), Jai Chand Rana et al., (2000), Bergale et al., (2001), Nimbalkar et al., (2002), Yousaf Ali, et al., (2008), Tsegaye et al., (2012), Yagd et al., (2012), Redhu et al., (1995), Walia and Garg (1996) and Hailegiorgis et al., (2011).

It is concluded that the distribution pattern of all the genotypes into various clusters showed the presence of considerable genetic divergence among the genotypes for most of the traits.

Plant height (ranked first 209 times) contributed 33.17 per cent to divergence of genotypes.

The intra cluster distances ranged from 0.000 (cluster IV) to 61.736 (cluster V).

The number of cluster VI and V showed maximum divergence (inter-cluster distance = 340.773) followed by members of cluster $\mathrm{V}$ and VI (inter-cluster distance 283.096).

The trait plant height is highest mean values (112.491) for cluster number $\mathrm{V}$ and low mean values (77.120) for cluster number VI.

The genotypes in cluster II may be used for the improvement of plant height and day of $50 \%$ flowering in cluster VI in wheat.

\section{References}

Bergale, S., B. Mridula, A.S. Holkar, K.N. Ruwali and S.V.S. Prasad. 2002. Pattern of variability, character association and path analysis in wheat (Triticum aestivum L.). Agric. Sci. Digest, 22(4): 258-260.

Dewey, J.R. and K.H. Lu. 1959. A correlation and path coefficient analysis components of crested wheat grass seed production. Agron.
J., 51: 515-518.

Gupta, R. S.; Singh, R. P. and Tiwari, D. K. (2004). Analysis of heritability and genetic advance in bread wheat (Triticum aestivum L. Em.Thell.). Advances in Plant Sciences, 17 (1): 301-305.

Hailegiorgis D, Mesfin M, Genet T (2011). Genetic Divergence Analysis on some Bread Wheat Genotypes Grown in Ethiopia. J. Cen. Europ. Agric. 12(2):344352.

Jai Chand Rana and Baldev Dass Sharma.2000, Variation, genetic divergence and interrelationship analysis in wheat, National Bureau of Plant Genetic Resources. Regional Station, Phagli, Shimla-171004, India.

Mahalanobis, P.C. 1936. The generalized distance in statistics. Pro. India Nat. Inst. Sci. 2:4955 .

Nimbalkar, C.A., Navale, P.A. and Biradar, A.B. (2002). Generalized $D^{2}$ and Genetic Diversity in Wheat. Journal of Maharashtra Agricultural Universities, 27(1): 43-45.

Radhu, A. S., S. K. Solanki, and I.Singh, 1995. Genetic diversity in some Indian and exotic wheat varieties. Crop Improvement, 22(2): 214-217.

Tsegaye D, Dessalgn T, Dessalegn Y, Share G (2012). Analysis of genetic diversity in some durum wheat (T. Durum) genotypes grown in Ethiopia. Afr. J. Biotechnol. 11(40): 9606 - 9611.

Walia, D.P. and Garg, D.K. 1996. Evaluation of genetic divergence in wheat (Triticum aestivum L.) germplasm. Indian Journal of Genetics 56:452-457.

Yousaf Ali, B. M. Atta, J. Akhter, P. Monneveux and Z. Lateef, 2008. Genetic variability, association and diversity studies in wheat (Triticum aestivum 1.) germplasm

Pak. J. Bot., 40(5): 2087-2097.

\section{How to cite this article:}

Ajeet Kumar, S.S. Gaurav, Amit Kumar and Vikas Rathi. 2017. Genetic Divergence Analysis of Agronomic Traits in Bread Wheat (Triticum aestivum L.) Genotypes. Int.J.Curr.Microbiol.App.Sci. 6(8): 2683-2686. doi: https://doi.org/10.20546/ijcmas.2017.608.320 